論 文

\title{
高圧水銀ランプバイパス回路共用複数灯点灯回路 一始動特性と消灯ランプ発生時の特性一
}

\author{
非会員 野 中 正 綱（株式会社九電工）正会員 家 村 道 雄 (崇城大学, 旧名：熊本工業大学)
}

\section{The Operating Circuits with a Common By-pass Circuit for Multiple High-pressure Mercury Discharge Lamp - Characteristics of Circuit during Start-up and When a Lamp does not Light-}

Non-Member Tadatsuna Nonaka (Kyudenko Co. Ltd.) and

Member Michio Iemura (Sojo University, Formerly: Kumamoto Institute of Technology)

\begin{abstract}
Using both simulation and experiments, we investigated cause to ensure that the supply current in an electrical circuit with a common by-pass circuit can be kept approximately constant from start-up to reaching steady state. In such circuit, the supply current can be distorted by about $2 \%$ when the power factor reaches $100 \%$. We found that an approximately constant supply current can be achieved, thus making these circuits practical for use with multiple high-pressure mercury discharge lamps, even when a lamp does not light.
\end{abstract}

KEYWORDS : multiple operating circuits, common by-pass circuit, starting characteristic

\section{1.はじめに}

高圧水銀ランプ等の HID ランプの高周波点灯回路は音響的共 鳴現象を伴うので, それを回避できる点灯回路に守る必要がある。 したがって，高価格になり形状も大きくなるため, HID ランプの 高周波点灯回路の実用化は小容量のランプについては実用化が 徐々に進んでいるが, 大容量のランプについては, 現在も磁気回 路式点灯回路が多く用いられている。

磁気叫路式の高压水銀ランプ点灯回路の中では, 遅相形点灯回 路が安価で安定器損失が少ないため, 道路や野球場, 体育館等の 照明として広く用いられている。しかし，基本波電流に対して第 3 , 第 5 調波電流の和が $10 １ 5 \%$ ぼ流れ，力率は60～70\%程度

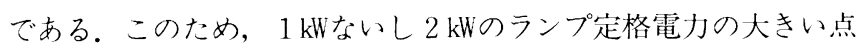
灯回路やランプ灯数が多くなると, HID ランプ用の専用変圧器の 磁気飽和作用により電源電流波形のひずみが著しくなることがあ る.このような場合, 高力率にするために入力端子にコンデンサ を接続する方法があるが, 電源電流の高調波成分がさらに大きく なり, 結果として電源電圧波形のひずみが大きくなり, 力率改善 が難しくなる。そこで, 専用変圧器の電源電圧波形に著しいひず みが生じないように変圧器容量を大きくする必要がある。また, 遅相形点灯回路では, 定格電流の1.5倍〜 1.8倍の始動電流が流れ るため, 必然的に電源の開閉器の電流容量が大きくなる.

したがって，点灯回路の電源側の電流波形の高調波成分を小さ く抑制し, 力率改善用コンデンサなしに力率をほぼ100\%に改善で きれば, 専用変圧器の電源電圧波形をひずませる恐れがなく, 適
正な谷量の専用変压器を選定できる. また, 始動電流が定格電流 とほぼ等しい点灯回路が実現できれば, 電源の開閉器の電流容量 を小さくすることが可能で，省エネルギー上も有利である.

著者の一人は, さきに高圧水銀ランプ道相形点灯回路を土夫し た同相形点灯回路について報告した ${ }^{1)}$. 定格インダクタンスの値 よりやや大きい自しインダクタンス分をもつ安定器巻線の途中か らバイパス回路を設け，バイパス回路の夕ップ位置と回路定数を 適正に定めることで, 電源電流のひずみ率が小さく, 力率がほぼ $100 \%$ の理想的な点灯回路を示した.

さらに, 著者らはそれぞれの安定器卷線の途中から1つのバイパ 又回路を共用した複数灯点灯回路について報告した ${ }^{233}$. すなわ ち, 回路定数, タップ位置を適正值に定め, 安定器卷線の電源側 に適正值の抵抗を接続することによりすべてのランプが同時に放 電を開始し，安定時のひずみ率が $2 \%$, 力率がほぼ100\%のバイパ 又回路共用複数灯点灯回路の実現が可能であることを示した。ま た，1つのバイパス回路を複数の点灯回路で共用することにより， 個々の点灯回路にバイパス回路を設けるより安価にすることがで きる。

本論文では，高圧水銀ランプバイパス回路共用複数灯点灯回路 の電源電流の大きさが始動時から岀定時までほぼ一定となる起因 を示すとともに, 従来の遅相形点灯回路との比較を示亦。また, シミュレーション及び実験により，この複数灯点灯回路に消灯ラ ンプが発生した場合の特性などについても示す. 


\section{2. 始動特性}

\section{1 始動時の点灯回路理論}

図 1 に高压水銀ランプバイパス回路共用複数灯点灯回路の回路 困を示す. ランプ灯数を $K$, 安定器のタップから電源側, ランプ 側の卷数をそれぞれ $N_{1}, N_{2}$, 同じく電源側, ランプ側のインダク タンス, 直流抵抗をそれぞれ $L_{1}, R_{1}, L_{2}, R_{2}$, バイパス回路の千 ヨークコイルのインダクタンス, 直流抵抗をそれぞれ $L_{\mathrm{b}}, R_{\mathrm{b}}$, コ ンデンサ容量を $C_{\mathrm{b}}$ とし，ランプのみ非線形素子とする．また，電 源の始動時の電压, 電流をそれぞれ $v_{\mathrm{s}}, i_{\mathrm{s}}$ とし, ランプの始動時の 電圧，電流をそれぞれ $v_{\mathrm{L}}, i_{\mathrm{L}}$ とする，なお， $R_{\mathrm{S}}$ は複数灯のランプ を同時に始動することを可能にする始動抵抗で，点灯した瞬間に スイッチ SWにより短絡する。

いま, 安定器の始動時の磁束 $\phi$ を

$$
\phi=g(i)
$$

とする。

関数 $g(i)$ は励磁電流 $i(t)$ が決まると, 磁束 $\phi(t)$ が決まるもの とし，ヒステリシス特性を示す関数とする，この場合，起磁力は $N_{1} i_{\mathrm{S}}+N_{2} i_{\mathrm{L}}$ であるので,

$$
i \cong \frac{1}{N_{1}+N_{2}}\left(N_{1} i_{\mathrm{S}}+N_{2} i_{\mathrm{L}}\right)
$$

と $i$ を定義すれば，(1)式が成立する.

図1の回路において次式が成立する。

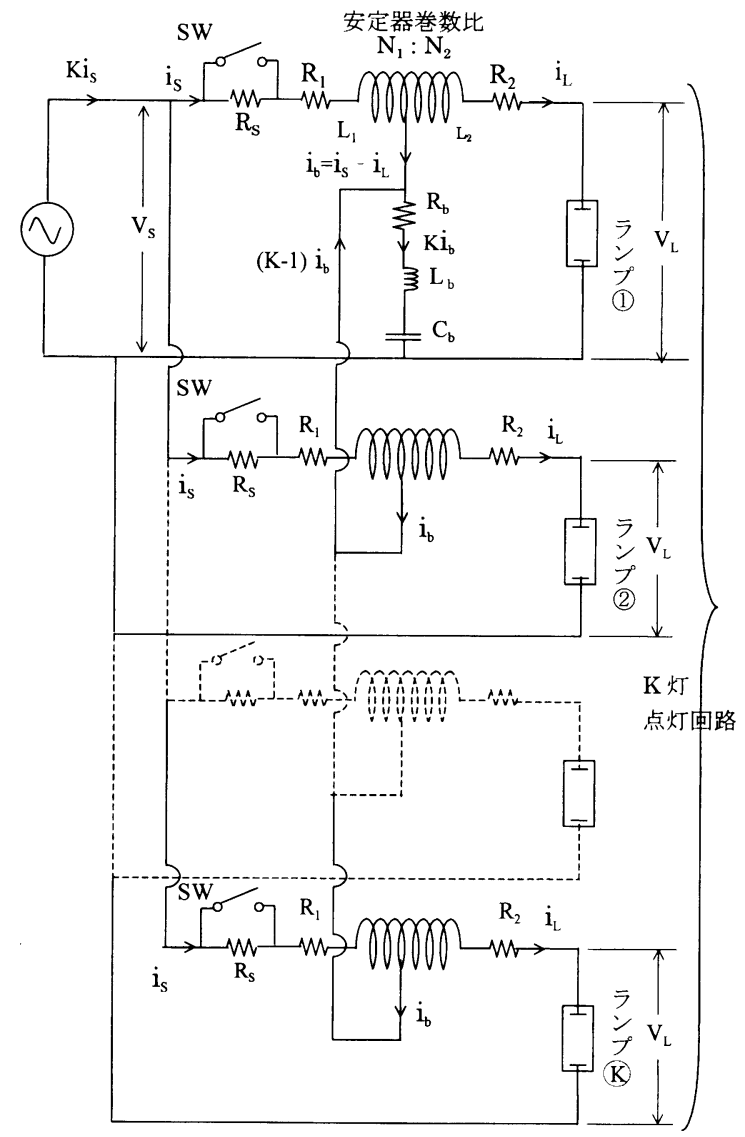

図 1 バイパス回路共用複数灯点灯回路

Fig. 1 The operating circuits with a common by-pass circuit for multiple lamps.

$$
\begin{aligned}
& v_{s}=N_{1} \frac{\mathrm{d} \phi}{\mathrm{d} t}+R_{1} i_{s}+K I_{\mathrm{b}} \frac{\mathrm{d}\left(j_{\mathrm{s}}-i_{1}\right)}{\mathrm{d} t} \\
& +K R_{\mathrm{b}}\left(i_{\mathrm{S}}-i_{\mathrm{L}}\right)+\frac{K}{C_{\mathrm{b}}} \int\left(i_{\mathrm{S}}-i_{\mathrm{L}}\right) \mathrm{d} t \\
& v_{\mathrm{L}}=-N_{2} \frac{\mathrm{d} \phi}{\mathrm{d} t}+R_{2} i_{\mathrm{L}}+K L_{\mathrm{b}} \frac{\mathrm{d}\left(i_{\mathrm{S}}-i_{\mathrm{L}}\right)}{\mathrm{d} t} \\
& +K R_{\mathrm{b}}\left(i_{\mathrm{S}}-i_{\mathrm{L}}\right)+\frac{K}{C_{\mathrm{b}}} \int\left(i_{\mathrm{S}}-i_{\mathrm{L}}\right) \mathrm{dt} \\
& \text { ここで, } \\
& \tau=\omega t, \omega=2 \pi f
\end{aligned}
$$

とおく.ただし，

(4)式より(3)式は, 次式となる.

$$
\left.\begin{array}{rl}
v_{\mathrm{S}}=\omega & N_{1} \frac{\mathrm{d} \phi}{\mathrm{d} \tau}+R_{1} i_{\mathrm{S}}+K \omega L_{\mathrm{b}} \frac{\mathrm{d}\left(i_{\mathrm{S}}-i_{\mathrm{L}}\right)}{\mathrm{d} \tau} \\
& +K R_{\mathrm{b}}\left(i_{\mathrm{S}}-i_{\mathrm{L}}\right)+\frac{K}{\omega C_{\mathrm{b}}}-\int\left(i_{\mathrm{S}}-i_{\mathrm{L}}\right) \mathrm{d} \tau \\
v_{\mathrm{L}}=- & \omega N_{2} \frac{\mathrm{d} \phi}{\mathrm{d} \tau}-R_{2} i_{2}+K \omega L_{\mathrm{b}} \frac{\mathrm{d}\left(i_{\mathrm{S}}-i_{\mathrm{L}}\right)}{\mathrm{d} \tau} \\
& +K R_{\mathrm{b}}\left(i_{\mathrm{S}}-i_{\mathrm{L}}\right)+\frac{K}{\omega C_{\mathrm{b}}} \int\left(i_{\mathrm{S}}-i_{\mathrm{L}}\right) \mathrm{d} \tau
\end{array}\right\}
$$

図 2 にバイパス回路共用複数灯点灯回路の始動特性を示寸。た だし, ランプの定格電力は $200 \mathrm{~W}$ ，ランプ灯数は 4 灯，バイパス回 路のタップ位置は $1 / 5$ である。始動時のランプ電圧, 電流は水 銀蒸気圧の上昇とともに時間変化し，図 2 のように緩やかに変化 するので, 電圧, 電流の各調波の時間振幅のみゆっくり変化する ものとして, 近似解法を行う。

ランプの特性を考虑して, 電源電圧・電流, ランプ電压・電流 は次式で表せる。

$$
\left.\begin{array}{l}
v_{\mathrm{S}}(\tau)=\sum_{n=0}^{\infty} v_{\mathrm{S} .2 n+1}(\tau) \sqrt{2} \cos \left\{(2 n+1) \tau+\psi_{\mathrm{S} .2 n+1}\right\} \\
v_{\mathrm{L}}(\tau)=\sum_{n=0}^{\infty} v_{\mathrm{L} .2 n+1}(\tau) \sqrt{2} \cos \left\{(2 n+1) \tau+\psi_{\mathrm{L} .2 n+1}\right\} \\
i_{\mathrm{S}}(\tau)=\sum_{n=0}^{\infty} I_{\mathrm{S} .2 n+1}(\tau) \sqrt{2} \cos \left\{(2 n+1) \tau+\theta_{\mathrm{S} .2 n+1}\right\} \\
i_{\mathrm{L}}(\tau)=\sum_{n=0}^{\infty} I_{\mathrm{L} .2 n+1}(\tau) \sqrt{2} \cos \left\{(2 n+1) \tau+\theta_{\mathrm{L} .2 n+1}\right\}
\end{array}\right\} \quad \cdots \cdots \cdots(6)
$$
電源電圧・電流，ランプ電圧・電流の電源電圧基本成分に対する 位相角を示军。また，(1)式より，

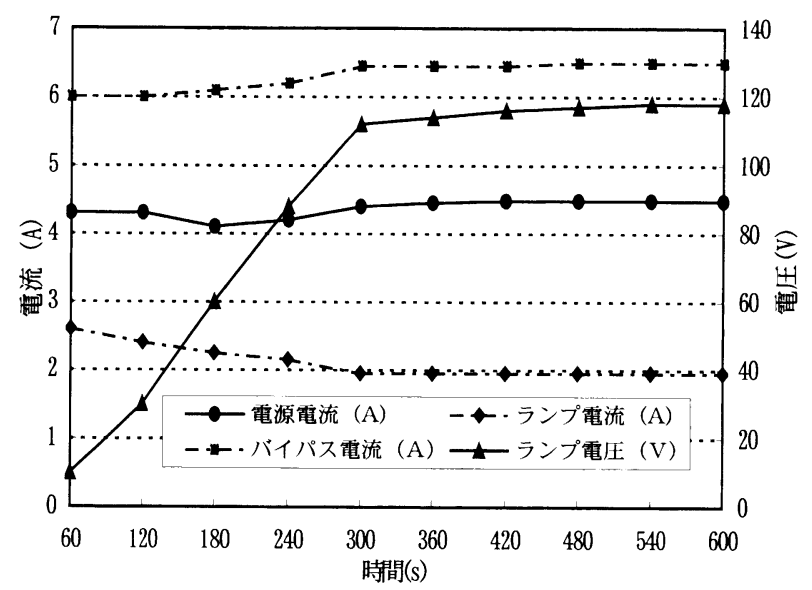

図 2 バイパス回路共用複数灯点灯回路の始動特性

Fig. 2 The start characteristics of the operating circuits with a common by-pass circuit for multiple lamps. 
$\phi(\tau)=\sum_{n=0}^{\infty} \Phi(\tau) \sqrt{2} \cos \left\{(2 n+1) \tau+\alpha_{2 n+1}\right\}$

ただし $, n=0,1,2 \cdots \cdots$.

(6)，(7)式を複素表現を用いると，次式となる.

$\left.\begin{array}{l}v_{\mathrm{S}}(\tau) \cong \operatorname{Re}\left[\sum_{n=0}^{\infty} \dot{V}_{\mathrm{S} .2 n+1}(\tau) \sqrt{2} e^{\mathrm{j}(2 n+1) r}\right. \\ v_{\mathrm{L}}(\tau) \cong \operatorname{Re}\left[\sum_{n=0}^{\infty} \dot{V}_{\mathrm{L} .2 n+1}(\tau) \sqrt{2} e^{\mathrm{j}(2 n+1) r}\right. \\ i_{\mathrm{S}}(\tau) \cong \operatorname{Re}\left[\sum_{n=0}^{\infty} \dot{I}_{\mathrm{S} .2 n+1}(\tau) \sqrt{2} e^{\mathrm{j}(2 n+1) r}\right. \\ i_{\mathrm{L}}(\tau) \cong \operatorname{Re}\left[\sum_{n=0}^{\infty} \dot{I}_{\mathrm{L} .2 n+1}(\tau) \sqrt{2} e^{\mathrm{j}(2 n+1) r}\right. \\ \phi(\tau) \cong \operatorname{Re}\left[\sum_{n=0}^{\infty} \dot{\Phi}_{2 n+1}(\tau) \sqrt{2} e^{\mathrm{j}(2 n+1) r}\right]\end{array}\right\}$

ただし，

$\dot{V}_{\mathrm{S} .2 n+1}(\tau)=V_{\mathrm{S} .2 n+1}(\tau) \sqrt{2} e^{\mathrm{j} \psi}{ }_{\mathrm{S} .2 n+1}$

$\dot{V}_{\mathrm{L} .2 n+1}(\tau)=\mathrm{V}_{\mathrm{L} .2 n+1}(\tau) \sqrt{2} \mathrm{e}^{\mathrm{j} \psi}{ }_{\mathrm{L} .2 n+1}$

$\dot{I}_{\mathrm{S} .2 n+1}(\tau)=\mathrm{I}_{\mathrm{S} .2 n+1}(\tau) \sqrt{2} \mathrm{e}^{\mathrm{j} \theta}{ }_{\mathrm{S} .2 n+1}$

$\dot{I}_{\mathrm{L} .2 n+1}(\tau)=\mathrm{I}_{\mathrm{L} .2 n+1}(\tau) \sqrt{2} \mathrm{e}^{\mathrm{j} \theta}{ }_{\mathrm{L} .2 n+1}$

$\dot{\Phi}_{2 n+1}(\tau)=\Phi_{2 n+1}(\tau) \sqrt{2} \mathrm{e}^{\mathrm{j} \alpha}{ }_{2 n+1}$

..(8)

ここで，ランプ電压 $v_{\mathrm{L}}$, 電流 $i_{\mathrm{L}}$ の振幅の変化が緩やかであるの で, 電源電流 $i_{\mathrm{S}}$, 磁束 $\phi$ のそれぞれの振幅変化も緩やかであると 考えられる。したがって，次式が成立する。

$$
\left.\begin{array}{l}
(2 n+1) \Phi_{2 n+1} \gg \frac{\mathrm{d} \Phi_{2 n+1}(\tau)}{\mathrm{d} \tau} \\
(2 n+1) I_{\mathrm{S} .2 n+1} \gg \frac{\mathrm{d} I_{\mathrm{S} .2 n+1}(\tau)}{\mathrm{d} \tau} \\
(2 n+1) I_{\mathrm{L} .2 n+1} \gg \frac{\mathrm{d} I_{\mathrm{L} .2 n+1}(\tau)}{\mathrm{d} \tau}
\end{array}\right\}
$$

(8)，(9)，(10)式より，(5)式は，

$$
\begin{aligned}
\sum_{n=0}^{\infty} & \dot{V}_{\mathrm{S} .2 n+1}(\tau) \\
= & \sum_{n=0}^{\infty}\left[\mathrm{j}(2 n+1) \omega N_{1} \dot{\Phi}_{2 n+1}(\tau)+R_{1} \dot{I}_{\mathrm{S} .2 n+1}(\tau)\right. \\
& +\left\{K \cdot R_{\mathrm{b}}+\mathrm{j}(2 n+1) K \cdot \omega L_{\mathrm{b}}+\frac{K}{\mathrm{j}(2 n+1) \omega C_{\mathrm{b}}}\right\} \\
& \left.\times\left\{\dot{I}_{\mathrm{S} .2 n+1}(\tau)-\dot{I}_{\mathrm{L} .2 n+1}(\tau)\right\}\right] \\
\sum_{n=0}^{\infty} & V_{\mathrm{L} .2 n+1}(\tau) \\
= & \sum_{n=0}^{\infty}\left[-\left\{\mathrm{j}(2 n+1) \omega N_{2} \dot{\Phi}_{2 n+1}(\tau)+R_{2} \cdot I_{\mathrm{L} .2 n+1}(\tau)\right]\right. \\
& +\left\{K \cdot R_{\mathrm{b}}+\mathrm{j}(2 n+1) K \cdot \omega L_{\mathrm{b}}+\frac{K}{\mathrm{j}(2 n+1) \omega C_{\mathrm{b}}}\right\} \\
& \left.\times\left\{\dot{I}_{\mathrm{S} .2 n+1}(\tau)-\dot{I}_{\mathrm{L} .2 n+1}(\tau)\right\}\right]
\end{aligned}
$$

となる。また，(2)，(6)式より，

$$
\dot{I}_{2 n+1}(\tau)=\frac{N_{1}}{N_{1}+N_{2}} \dot{I}_{\mathrm{S} .2 n+1}(\tau)+\frac{N_{2}}{N_{1}+N_{2}} \dot{I}_{\mathrm{L} .2 n+1}(\tau)
$$

ここで，回路的な意味をはっきりさせるために，次の量を定義 する。

$$
\begin{aligned}
& \dot{L}_{2 n+1}(\tau) \cong \frac{\dot{\Phi}_{2 n+1}(\tau)}{\dot{I}_{2 n+1}(\tau)} \\
& \dot{L}_{1.2 n+1}(\tau) \cong \frac{N_{1}{ }^{2}}{N_{1}+N_{2}} \dot{L}_{2 n+1}(\tau) \\
& \dot{L_{2.2 n+1}}(\tau) \cong \frac{N_{2}{ }^{2}}{N_{1}+N_{2}} \dot{L}_{2 n+1}(\tau) \\
& \dot{M}_{2 n+1}(\tau) \cong \frac{N_{2} N_{2}}{N_{1}+N_{2}} \dot{L}_{2 n+1}(\tau) \\
& \dot{L_{\mathrm{b} .2 n+1}}(\tau) \cong \frac{N_{\mathrm{b}} \Phi_{\mathrm{b} .2 n+1}(\tau)}{\dot{I}_{1.2 n+1}(\tau)-I_{2.2 n+1}(\tau)}
\end{aligned}
$$$$
\}
$$

\section{,}




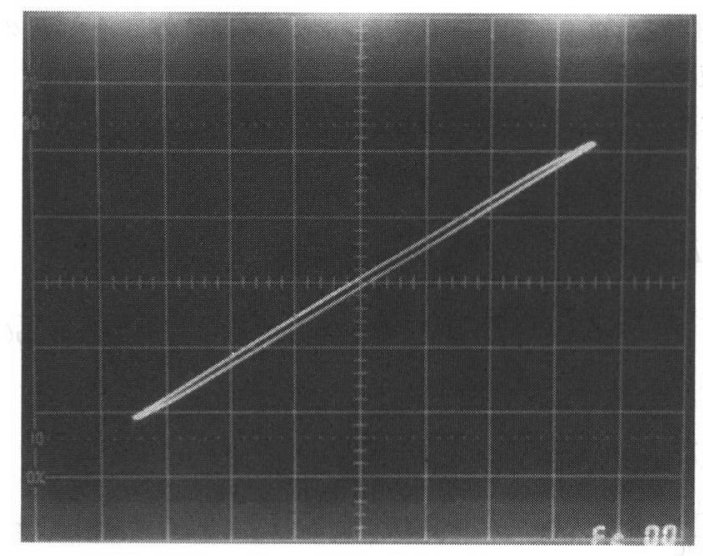

横軸：電流 $1 \mathrm{~A} / \mathrm{div}$, 縦軸：鎖交磁束 $0.025 \mathrm{wb} / \mathrm{div}$ 图 3 安定器のヒステリシス特性

Fig. 3 Hysteresis Characteristic of ballast.

$\sum_{n=0}^{\infty} \dot{V}_{\mathrm{L} .2 n+1}(\tau)$

$=\sum_{n=0}^{\infty}\left[-\dot{I}_{\mathrm{L} .2 n+1}(\tau)\left\{\gamma_{2.2 n+1}+\mathrm{j}(2 n+1) \omega\left(L_{2}+M\right)\right\}\right.$

$+\left\{K \cdot r_{\mathrm{b} .2 n+1}+\mathrm{j}(2 n+1) K \cdot \omega\left\{L_{\mathrm{b}}-\frac{M}{K}\right\}\right.$

$\left.+\frac{K}{\mathbf{j}(2 n+1) \omega C_{\mathrm{b}}}\right\} \times\left\{\dot{I}_{\mathrm{S} .2 n+1}(\tau)-\dot{I}_{\mathrm{L} .2 n+1}(\tau)\right\}$

ただし,

$r_{1.2 n+1}=R_{1}+(2 n+1) \omega\left(L_{1.2 n+1}^{\prime}+M_{2 n+1}^{\prime}\right)$

$r_{2.2 n+1}=R_{2}+(2 n+1) \omega\left(L_{2.2 n+1}^{\prime}+M_{2 n+1}^{\prime}\right)$

$\gamma_{\mathrm{b} .2 n+1}=R_{\mathrm{b}}+(2 n+1) \omega\left(L_{\mathrm{b} .2 n+1}^{\prime}-\frac{M_{2 n+1}^{\prime}}{K}\right)$

いま, 入力端子に基本波電圧 $\dot{E} の$ み存在するものとし, (19)式にお いて調和平衡法を適用すると, 基本波回路と第 $3,5,2 n+1$ 調波 回路の 1 灯分の近似等価回路は それぞれ図4 (a)，(b)のようにな る.

ここで, ランプより発生する第 3 , 第 5 調波などの高調波電流 は主にバイパス回路に流れる。また, 実験により始動時から安定 時まで電源電流のひずみ率は $2.5 \%$ 以下であることがわかった.し たがって，電源電流にはほぼ基本波のみが流れていると考えてよ いので，電源電流の始動特性は図 4 (a)の基本波回路を用いて考察 する.

\section{3 始動特性の考察}

図 4 (a)の基本波回路において，ランプの基本波インピーダンス を $\dot{Z}_{\mathrm{L} .1}(\tau)$ とすると， $(c)-\left(c^{\prime}\right)$ 端子よりランプ側のアドミタンス $\dot{Y}_{2.1}(\tau)$, バイパス回路のアドミタンス $\dot{Y}_{\mathrm{b}, 1}$ は(22)式で表せる.

$$
\left.\begin{array}{l}
\dot{Y}_{2.1}(\tau)=\frac{1}{r_{2.1}+\mathrm{j}_{\omega}\left(L_{2}+M\right)+\dot{Z}_{\mathrm{L} .1}(\tau)} \\
\dot{Y}_{\mathrm{b} .1}=\frac{1}{K r_{\mathrm{b} .1}+\mathrm{j} K \omega\left(L_{\mathrm{b}}-\frac{M}{K}\right)+\frac{K}{\mathrm{j} \omega C_{\mathrm{b}}}}
\end{array}\right\}
$$

(b) - (b') 端子よりランプ側の基本波アドミタンス $Y_{r .1}(\tau)$ と 基本波インピーダンス $\dot{Z}_{r .1}(\tau)$ は，(22)式より，

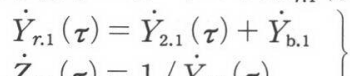
(23)

$$
\dot{Z}_{r .1}(\tau)=1 / \dot{Y}_{r .1}(\tau)
$$

となり, 入力端子 $(a)-\left(a^{\prime}\right)$ からランプ側をみた基本波インピー ダンスは,
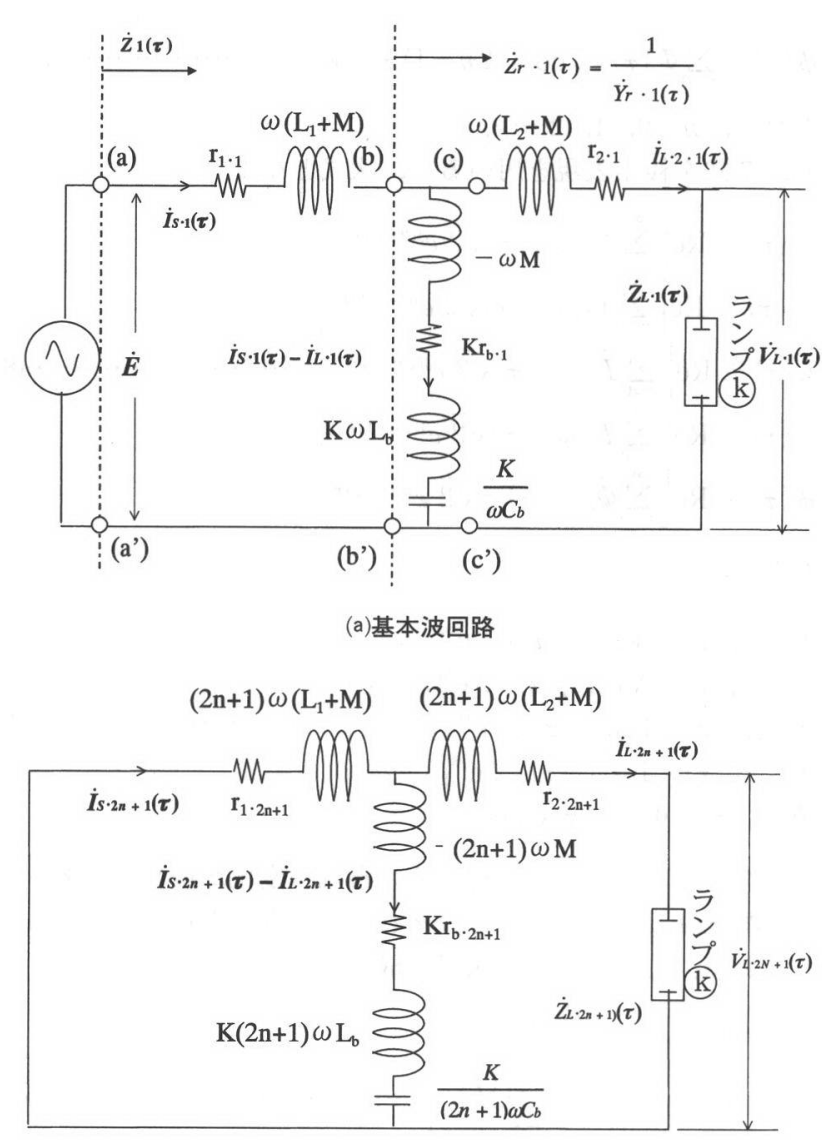

(b)第 3, 5, $\cdots 2 n+1$ 調波回路

図 4 始動時の等価回路（1 灯分）

Fig. 4 Equivalent circuit of starting condition.

$$
\dot{Z}_{1}(\tau)=r_{1.1}+\mathrm{j} \omega\left(L_{1}+M\right)+\dot{Z}_{r .1}(\tau)
$$

で表せる.

また，従来の遅相形点灯回路の入力端子から負荷側を見た基本 波インピーダンス $\dot{Z}^{\prime}{ }_{1}(\tau)$ は, 安定器の自己インダクタンスを $L$ $[\mathrm{H}]$ とすると，次式となる.

$\dot{Z}^{\prime}{ }_{1}(\tau)=r+\mathrm{j} \omega L+\dot{Z}_{\mathrm{L} .1}(\tau)$

表 1 に $200 \mathrm{~W}$ バイパス回路共用 4 灯点灯回路の回路定数を示 す.なお, 安定器の自己インダクタンスは $0.24[\mathrm{H}]$ である.この回 路に $200 \mathrm{~V}, 60 \mathrm{~Hz}$ を印加したときのランプの基本波インピーダン ス $\dot{Z}_{\mathrm{L} .1}(\tau)$ は, ランプ電圧, 電流の波形分析より図 5 のようになる. 図 5 より, ランプの基本波インピーダンス $\dot{Z}_{\mathrm{L} .1}(\tau)$ は, 始動から安 定状態に近づくにつれて，ランプのリアクタンス成分の大きさよ り抵抗成分の大きさの増加量が大きくなっている.

(22)式から $\dot{Y}_{2.1}(\tau)$ のベクトル軌跡は図 6 のようになる. 安定状態 に近づくにつれてランプの基本波インピーダンス $\dot{Z}_{\mathrm{L} .1}(\tau)$ が大き くなるため, $\dot{Y}_{2.1}(\tau)$ の大さは小さくなり, 容量性の方向に変化 している。また，(23)式から，(b)－( (b') 端子よりランブ側の基本波

表 $1200 \mathrm{~W}$ バイパス回路共用 4 灯点灯回路の回路定数

Table 1 Circuit constants of $200 \mathrm{~W}$ in the Operating Circuits with a Common By-pass Circuit for multiple lamps.

\begin{tabular}{|r|c|c|c|}
\hline$r_{1.1}[\Omega]$ & $R_{2,1}[\Omega]$ & $L_{1}[\mathrm{H}]$ & $L_{2}[\mathrm{H}]$ \\
\hline 1.444 & 5.785 & 0.0096 & 0.1536 \\
\hline \hline$M[\mathrm{H}]$ & $R_{\mathrm{b}, 1}[\Omega]$ & $L_{\mathrm{b}}[\mathrm{H}]$ & $C_{\mathrm{b}}[\mu \mathrm{F}]$ \\
\hline 0.0384 & 2.0 & 0.019 & 80 \\
\hline
\end{tabular}




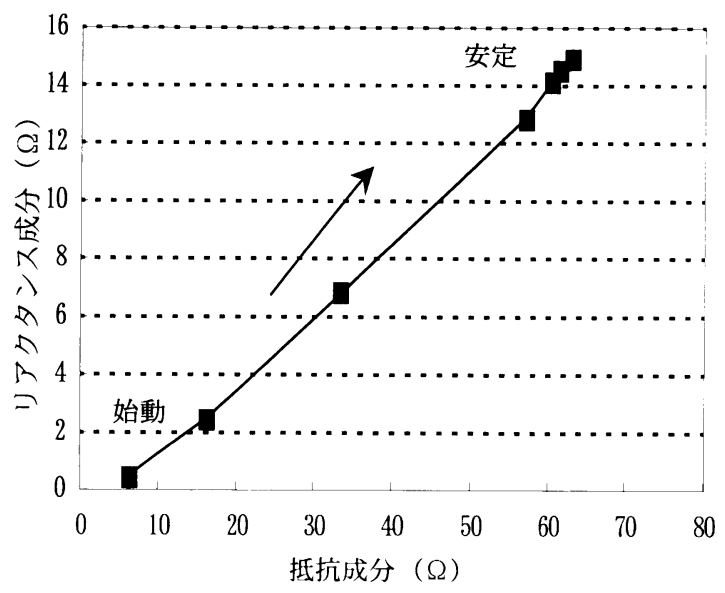

图 5 始動時のランプの基本波インピーダンス $\dot{Z}_{\mathrm{L} .1}(\tau)$ の変化 Fig. 5 Variation of on $Z_{\mathrm{L} .1}(\tau)$ starting condition.

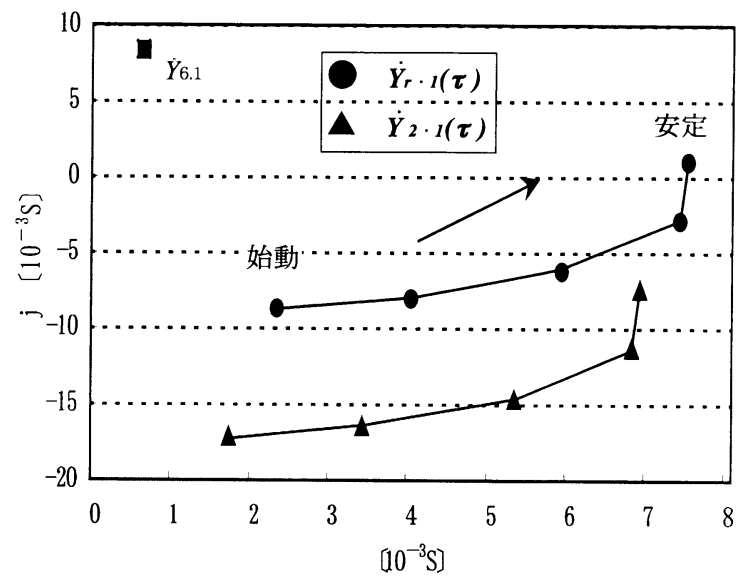

図 6 始動時の基本波アドミタンス $\dot{Y}_{2,1}(\tau)$ と $\dot{Y}_{r_{1}}(\tau)$ の変化

Fig. 6 Variation of $\dot{Y}_{2.1}(\tau)$ and $\dot{Y}_{r .1}(\tau)$ on starting condition.

アドミタンス $\dot{Y}_{r .1}(\tau)$ の軌跡は, 同四のようになる。適正なバイパ ス回路の回路定数を定めることでバイパス回路のアドミタンス $\dot{Y}_{\mathrm{b} .1}$ が $\dot{Y}_{r .1}(\tau)$ の大さをほぼ一定にする作用をしている.

(24)，(25)式から，バイパス回路共用 4 灯点灯回路の基本波インピ 一ダンス $Z_{1}(\tau)$ 及び従来の遅相形点灯回路の基本波インピーダン ス $\dot{Z}^{\prime}{ }_{1}(\tau)$ のベクトル軌跡を図 7 に示す。困 7 より, 従来の遅相形 点灯回路の基本波インピーダンス $\dot{Z}^{\prime}{ }_{1}{ }_{(\tau)}$ ( は, 安定状態に近づいて もリアクタンス成分は増加を続け，始動から安定状態まで常に誘 導性の状態にある。それに対しバイパス回路共用 4 灯点灯回路の 基本波インピーダンス $\dot{Z}_{1}(\tau)$ は，始動時はランプの抵抗成分が小 さいため誘導性であるが, 安定状態に近づくにつれリアクタンス 成分は減少し容量性の方向に変化し, 安定状態では抵抗成分のみ になる。したがって，バイパス回路共用 4 灯点灯回路の電源電流 は始動時においては遅れの状態であるが安定状態に近づくにつれ 進みの方向に変化し, 安定状態では力率はほほ $100 \%$ となる.

また，始動時から安定状態までの基本波インピーダンスの大き さの変化は, 図 8 より従来の遅相形点灯回路の基本波インピーダ ンス $\dot{Z}^{\prime}{ }_{1}(\tau)$ の大きが始動から安定状態に近づくにつれ徐々に 大きくなるのに対して，バイバス回路共用 4 灯点灯回路の基本波 インピーダンスの大きさは始動から安定状態まで常にほぼ一定で ある。したがって，バイパス回路共用 4 灯点灯回路の電源電流は 始動時から安定状態までほぼ一定値となる。

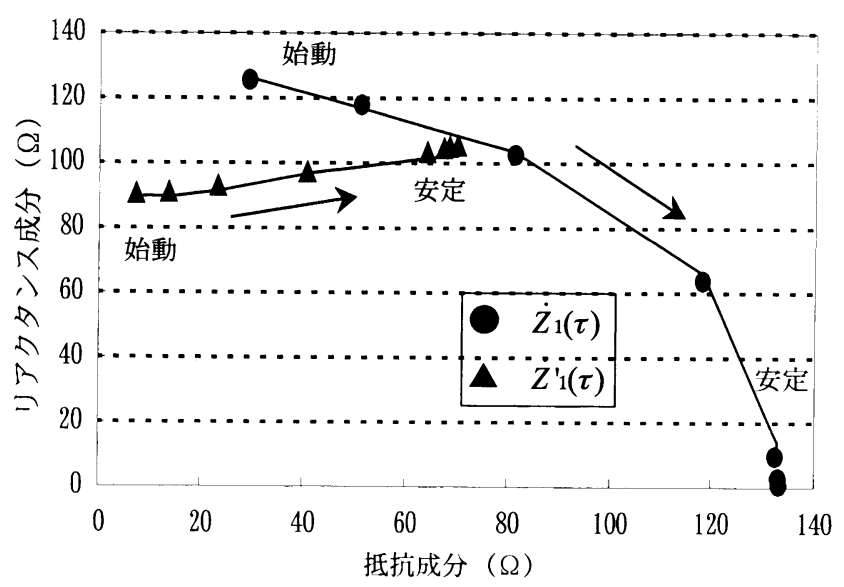

図 7 始動時のバイパス回路共用4灯点灯回路の基本波インピーダンス $\dot{Z}_{1}(\tau)$ と従来の遅相形点灯回路の基本波インピーダンス $\dot{Z}^{\prime}{ }_{1}(\tau)$ の变化

Fig. 7 Variation of $\dot{Z}_{1}(\tau)$ and $\dot{Z}^{\prime}{ }_{1}(\tau)$ on starting condition.

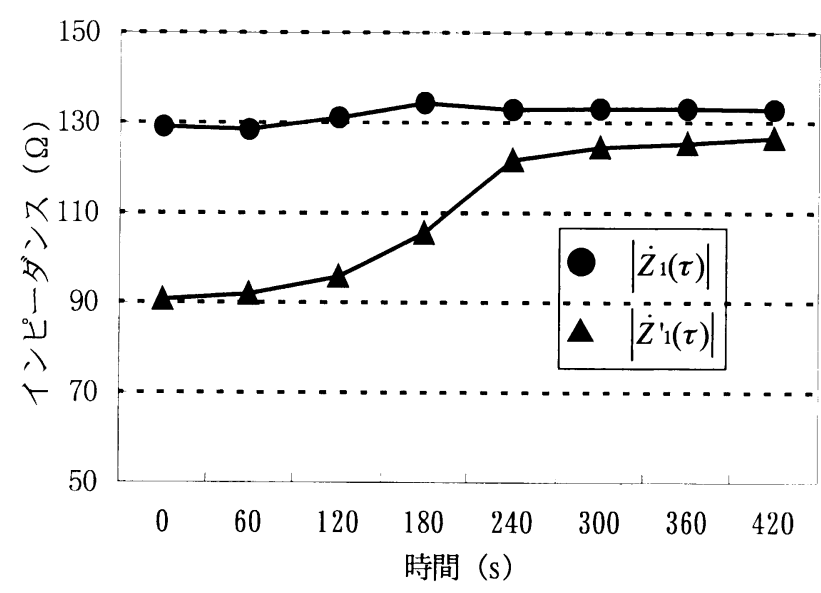

図 8 始動時のバイパス回路共用4灯点灯回路の基本波インピーダンス $\mid \dot{Z}_{1}(\tau)$ と従来の遅相形点灯回路の基本波インピーダンス $\left|\dot{Z}^{\prime}{ }_{1}(\tau)\right|$ の変化

Fig. 8 Variation of $\left|\dot{Z}_{1}(\tau)\right|$ and $\left|\dot{Z}^{\prime}{ }_{1}(\tau)\right|$ on starting condition.

これらのことより, バイパス回路共用複数灯点灯回路は，従来 の遅相形点灯回路にバイパス回路を設け回路定数を適正に定める ことにより，入力端子の基本波インピーダンス $\dot{Z}_{1}(\tau)$ のききを 一定にし，力率を $100 \%$ に近づける作用をしている事が分かる。し たがって，従来の遅相形点灯回路は，始動時に定格の1.5〜1.8倍 の始動電流が流れ，安定時の力率も60～70\%であるが，バイパス 回路共用複数灯点灯回路は，始動から穻定状態までほぼ一定の電 流となり，安定時には力率が $100 \%$ にることが分かる。また， $K$ 灯点灯回路においても，同様のことが言える.

図 9 に200W バイパス回路共用 4 灯点灯回路の電源電庄が30 $\mathrm{V}, 60 \mathrm{~V}, 123 \mathrm{~V}$ のきの電源電流波形を，図10に従来の遅相形点 灯回路 (4灯分) の電源電圧が $30 \mathrm{~V}, 60 \mathrm{~V}, 124 \mathrm{~V}$ のきの電源電 流波形をそれぞれ示す。

\section{3. 消灯ランプ発生時の特性}

\section{1 消灯ランプ発生時のシミュレーション}

バイパス回路共用複数灯点灯回路において，ランプが点灯中に 寿命や故障等により消灯した場合の回路に成立する式を以下に示 寺．K灯点灯回路において，K，灯のランプが消灯した場合の回路 四を図11に示寸。ここで，点灯しているランプのバイパス回路電 流を $i_{\mathrm{b} 1}$, 消灯しているランプのバイパス回路電流を $i_{\mathrm{b} 2}$ とする.

四11より求めた安定時の微分方程式は(26)（29)式となる. 


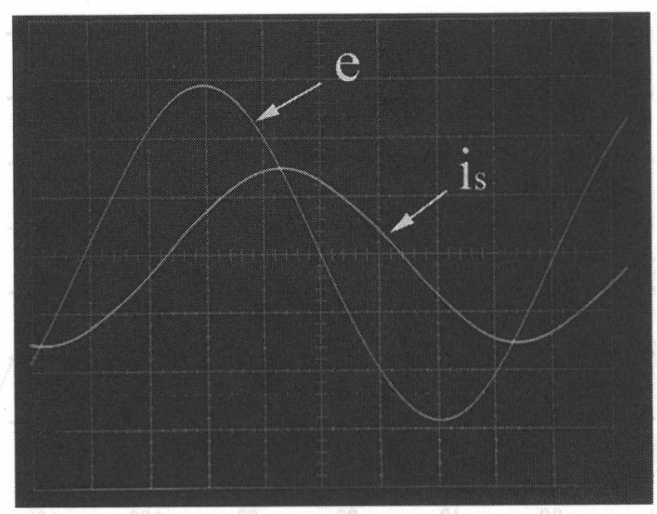

(a)ランプ電圧 $30 \mathrm{~V}$

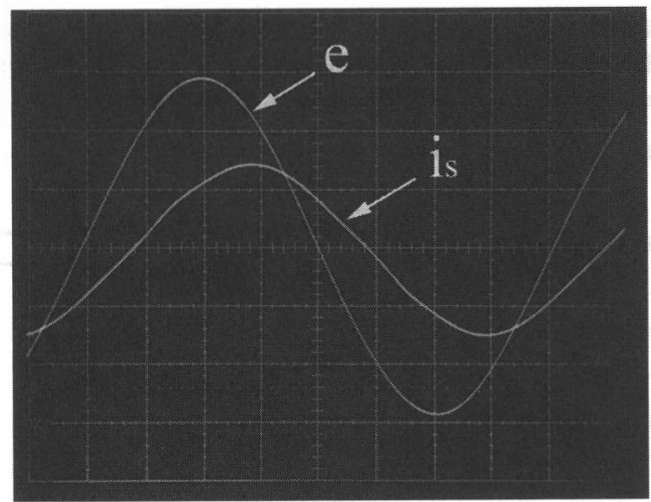

(b)ランプ電圧 $60 \mathrm{~V}$

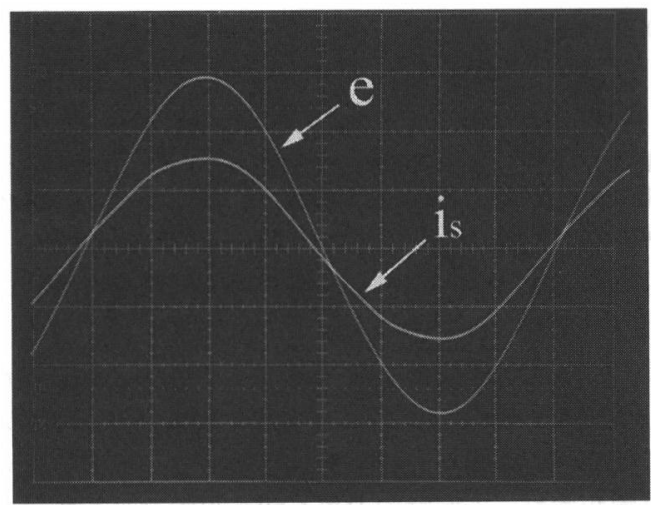

(c)ランプ電圧 $123 \mathrm{~V}$

図 $9200 \mathrm{~W}$ バイパス回路共用 4 灯点灯回路の電源電圧 e と電源電流 $I_{\mathrm{s}}$ の波形 (e : $\left.100 \mathrm{~V} / \mathrm{div}, 4 \times i_{\mathrm{S}}: 4 \mathrm{~A} / \mathrm{div}\right)$

Fig. 9 Supply voltage and supply current waveforms for $200 \mathrm{~W}$ operating circuits of four lamps on common by-pass circuit.

$$
\begin{aligned}
\frac{\mathrm{d} i_{\mathrm{L}}}{\mathrm{d} t}= & \frac{1}{J_{1}}\left(J_{2} \times i_{\mathrm{c}}+J_{3} \times i_{\mathrm{b} 1}+J_{4} \times i_{\mathrm{b} 2}\right. \\
& \left.+J_{5} \times V_{\mathrm{cb}}+J_{6} \times e+J_{7} \times \frac{1}{G} \times i_{\mathrm{L}}\right) \\
\frac{\mathrm{d} i_{\mathrm{b} 1}}{\mathrm{~d} t}= & \frac{1}{J_{8}}\left(e-J_{9} \frac{\mathrm{d} i_{\mathrm{L}}}{\mathrm{d} t}-J_{10} \times i_{\mathrm{L}}-\frac{i_{\mathrm{L}}}{G}-R_{2} \times i_{\mathrm{b} 1}\right) \\
\frac{\mathrm{d} i_{\mathrm{b} 2}}{\mathrm{~d} t}= & \frac{1}{J_{11}}\left[J_{22} \frac{\mathrm{d} i_{\mathrm{L}}}{\mathrm{d} t}+\left\{J_{13}+\left(K-K^{\prime}\right) L_{\mathrm{b}} \frac{1}{G}\right\} i_{\mathrm{L}}\right. \\
& \left.+J_{14} \times i_{\mathrm{b} 1}-J_{15} \times i_{\mathrm{b} 2}-J_{8} \times V_{\mathrm{cb}}-J_{16} \times e\right]
\end{aligned}
$$

$\frac{\mathrm{d} V_{\mathrm{cb}}}{\mathrm{d} t}=\frac{\left(K-K^{\prime}\right) i_{\mathrm{b} 1}+K^{\prime} i_{\mathrm{b} 2}}{C_{\mathrm{b}}}$

ただし, $G$ はランプの等価コンダクタンスで, $J_{1} \sim J_{16}$ は次式と

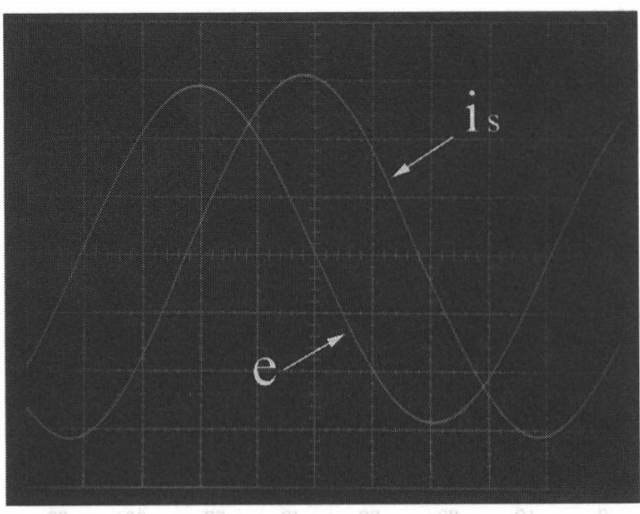

(a)ランプ電圧30 V

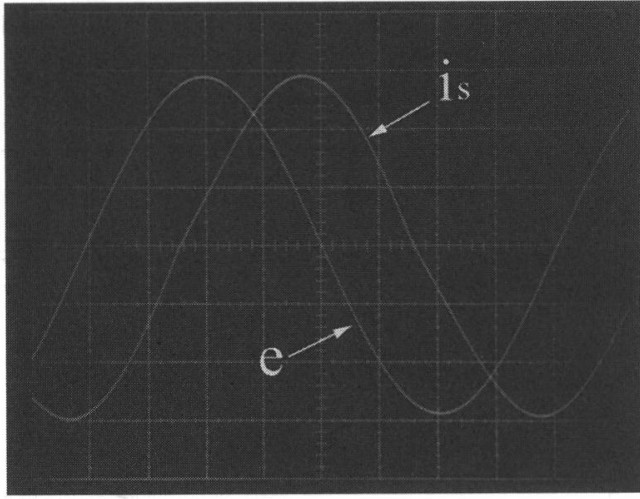

(b)ランプ電圧 $60 \mathrm{~V}$

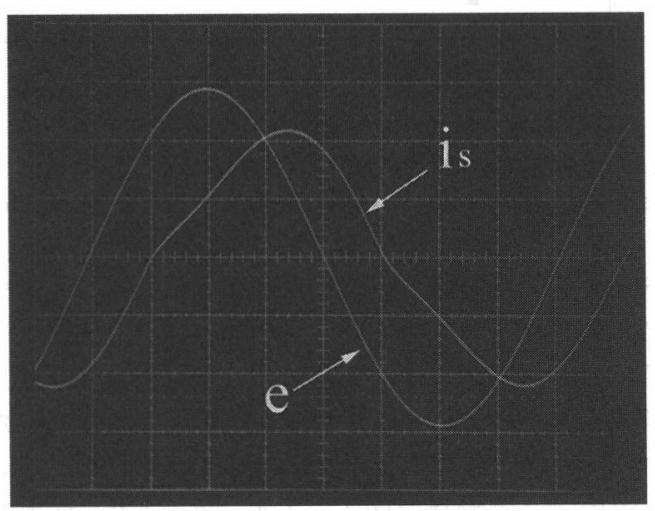

(c)ランプ電圧 $124 \mathrm{~V}$

図10 200W 遅相形点灯回路の電源電圧 $\mathrm{e}$ と電源電流 $I_{\mathrm{S}}$ の波形 ( 4 灯分) (e : $\left.100 \mathrm{~V} / \mathrm{div}, 4 \times i_{\mathrm{S}}: 4 \mathrm{~A} / \mathrm{div}\right)$

Fig.10 Supply voltage and supply current waveforms for $200 \mathrm{~W}$ lag type operating circuit.

する。

$$
\begin{aligned}
J_{1}= & \frac{1}{\left(L_{2}+M\right)\left(L_{2}+K^{\prime} L_{\mathrm{b}}\right)}\left\{\left(L_{2}+K^{\prime} L_{\mathrm{b}}\right)\left(L_{1} L_{2}-M^{2}\right)\right. \\
& \left.\quad+\left(K-K^{\prime}\right) L_{2} L_{\mathrm{b}}\left(L_{1}+L_{2}+2 M\right)\right\} \\
J_{2}= & \frac{1}{\left(L_{2}+M\right)\left(L_{2}+K^{\prime} L_{\mathrm{b}}\right)}\left(L_{2}+K^{\prime} L_{\mathrm{b}}\right) \\
\times & \left\{R_{2} M-\left(R_{1}+R_{\mathrm{S}}\right) L_{2}\right\}-\left(K-K^{\prime}\right) L_{2} L_{\mathrm{b}}\left(R_{1}+R_{\mathrm{S}}+R_{2}\right) \\
J_{3}= & \frac{1}{\left(L_{2}+M\right)\left(L_{2}+K^{\prime} L_{\mathrm{b}}\right)} \\
& \times\left[\left(L_{2}+K^{\prime} L_{\mathrm{b}}\right)\left\{R_{2} M-R_{\mathrm{Mb}}\left(L_{2}-M\right)\right\}\right. \\
& \left.+\left(K-K^{\prime}\right) L_{2}\left\{-R_{2} L_{\mathrm{b}}+R_{\mathrm{b}}\left(L_{2}+M\right)\right\}\right]
\end{aligned}
$$




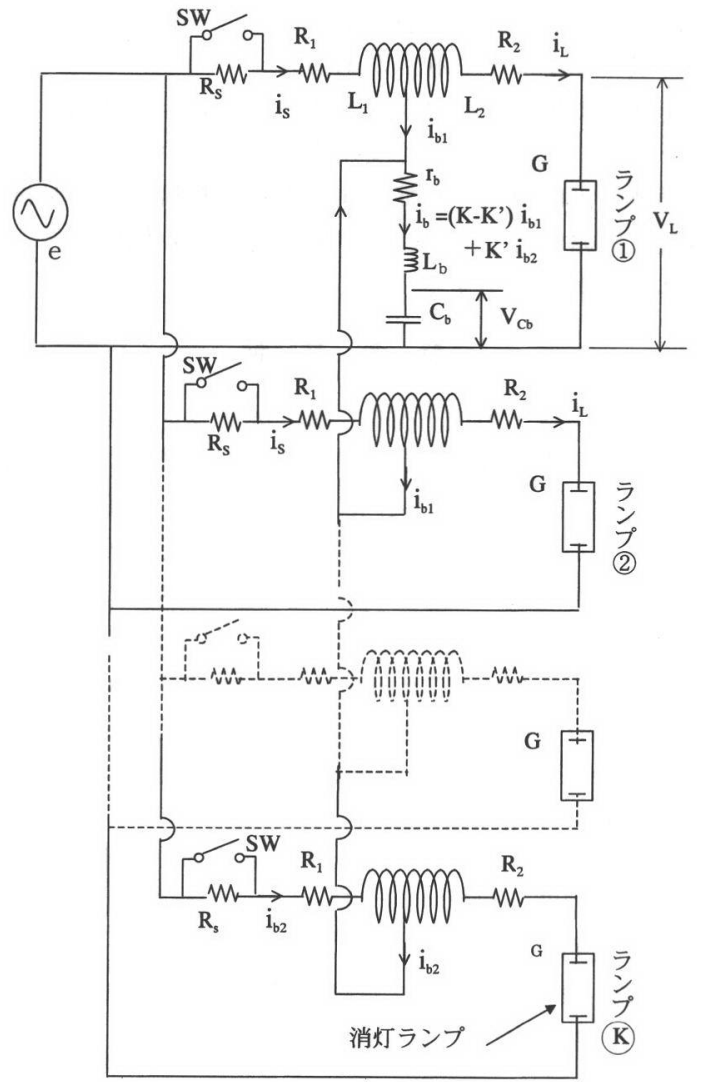

図11 消灯ランプ発生時の点灯回路

Fig.11 Operating circuit in case of the non- lighting lamp occurrence.

$J_{4}=\frac{K^{\prime}}{\left(L_{2}+K^{\prime} L_{\mathrm{b}}\right)}\left(L_{2} R_{\mathrm{b}}-R_{2} L_{\mathrm{b}}\right)$

$J_{5}=\frac{L_{2}}{\left(L_{2}+K^{\prime} L_{\mathrm{b}}\right)}$

$J_{6}=\frac{L_{2}}{\left(L_{2}+M\right)\left(L_{2}+K^{\prime} L_{\mathrm{b}}\right)}\left\{\left(K-K^{\prime}\right) L_{\mathrm{b}}-M+K^{\prime} L_{\mathrm{b}}\right\}$ $\cdots(30)$

$J_{7}=\frac{-L_{2}}{\left(L_{2}+M\right)\left(L_{2}+K^{\prime} L_{\mathrm{b}}\right)}\left\{\left(K-K^{\prime}\right) L_{\mathrm{b}}+L_{2}+K^{\prime} L_{\mathrm{b}}\right\}$

$J_{8}=L_{2}+M$

$J_{9}=L_{1}+L_{2}+2 M$

$J_{10}=R_{1}+R_{\mathrm{S}}+R_{2}$

$J_{11}=\left(L_{2}+M\right)\left(L_{2}+K^{\prime} L_{\mathrm{b}}\right)$

$J_{12}=\left(K-K^{\prime}\right) L_{\mathrm{b}}\left(L_{1}+L_{2}+2 M\right)$

$J_{13}=\left(K-K^{\prime}\right) L_{\mathrm{b}}\left(R_{1}+R_{\mathrm{S}}+R_{2}\right)$

$J_{14}=\left(K-K^{\prime}\right)\left\{L_{\mathrm{b}} R_{2}-\left(L_{2}+M\right) R_{\mathrm{b}}\right\}$

$J_{15}=\left(L_{2}+M\right)\left(R_{2}+K^{\prime} R_{\mathrm{b}}\right)$

$J_{16}=\left(K-K^{\prime}\right) L_{\mathrm{b}}-\left(L_{2}+M\right)$

また, 安定時には次式が成り立つ5).

$\frac{\mathrm{d} G}{\mathrm{~d} t}=A_{\mathrm{A}} \times i_{\mathrm{L}}{ }^{2}-C_{\mathrm{C}} \times G^{2}$

ただし， $A_{\mathrm{A}}, C_{\mathrm{C}}$ はモデル定数である.

(26) 〜(29)及び(31)式の五元連立微分方程式に $E$ や $A_{\mathrm{A}}, C_{\mathrm{C}}$ 等の值を 与える.さらに, 演算開始時間 $t=0$ における等価コンダクタンス $G_{0}$ の初期值を与之, ルンゲ・クッ夕法等を用いて, 安定時のステ ップ時間 $\Delta t$ ごとの $i_{\mathrm{L}}, i_{\mathrm{b} 1}, i_{\mathrm{b} 2}$ などを求めることができる.

表 2 に定格ランプ電力 $200 \mathrm{~W}$ のバイパス回路共用 4 灯点灯回路 に200Vの正弦波電圧を印加した時, 安定状態において 1 灯の消
表 2 消灯ランプ発生時のシミュレーションと実測結果

Table 2 Simulation and experimental results in case of the non- lighting lamp occurrence.

\begin{tabular}{|c|c|c|c|c|c|c|}
\hline タップ位置 & $\begin{array}{c}L_{1} \\
(\mathrm{H})\end{array}$ & $\begin{array}{c}L_{2} \\
(\mathrm{H})\end{array}$ & $\begin{array}{l}R_{1} \\
(\Omega)\end{array}$ & $\begin{array}{l}R_{2} \\
(\Omega)\end{array}$ & $\begin{array}{l}L_{\mathrm{b}} \\
(\mathrm{H})\end{array}$ & $\begin{array}{l}\mathrm{C}_{\mathrm{b}} \\
(\mu \mathrm{F})\end{array}$ \\
\hline $1 / 5$ & 0.0096 & 0.1536 & 1.446 & 5.784 & 0.019 & 80 \\
\hline \multirow{2}{*}{\multicolumn{2}{|c|}{ 消灯ランプ数 }} & \multicolumn{3}{|c|}{1 灯 } & \multicolumn{2}{|c|}{ 消灯ランプなし } \\
\hline & & \multicolumn{2}{|c|}{ シミュレーション } & 実測 & \multicolumn{2}{|c|}{ 実測 } \\
\hline 電 源 電 & 流 (A) & \multicolumn{2}{|c|}{4.98} & 4.85 & \multicolumn{2}{|c|}{4.61} \\
\hline 電 源 電 & 力 $(\mathrm{W})$ & \multicolumn{2}{|c|}{920.8} & 945 & \multicolumn{2}{|c|}{910} \\
\hline ランプ電里 & $V_{\mathrm{L}}(\mathrm{V})$ & \multicolumn{2}{|c|}{123.8} & 118 & \multicolumn{2}{|c|}{121.5} \\
\hline ランプ 電 & $i_{\mathrm{L}}(\mathrm{A})$ & \multicolumn{2}{|c|}{1.95} & 2.5 & \multicolumn{2}{|c|}{1.95} \\
\hline ランプ 電 & 力 $(W)$ & \multicolumn{2}{|c|}{218.7} & 260 & \multicolumn{2}{|c|}{220} \\
\hline \multicolumn{2}{|c|}{ バイパス電流 $i_{\mathrm{b}}(\mathrm{A})$} & \multicolumn{2}{|c|}{6.92} & 6.75 & \multicolumn{2}{|c|}{6.5} \\
\hline & 率（\%) & \multicolumn{2}{|c|}{92.5} & 97.4 & \multicolumn{2}{|c|}{98.7} \\
\hline \multicolumn{2}{|c|}{ 電源電流ひずみ率（\%） } & \multicolumn{2}{|c|}{1.14} & 1.67 & \multicolumn{2}{|c|}{2.03} \\
\hline
\end{tabular}

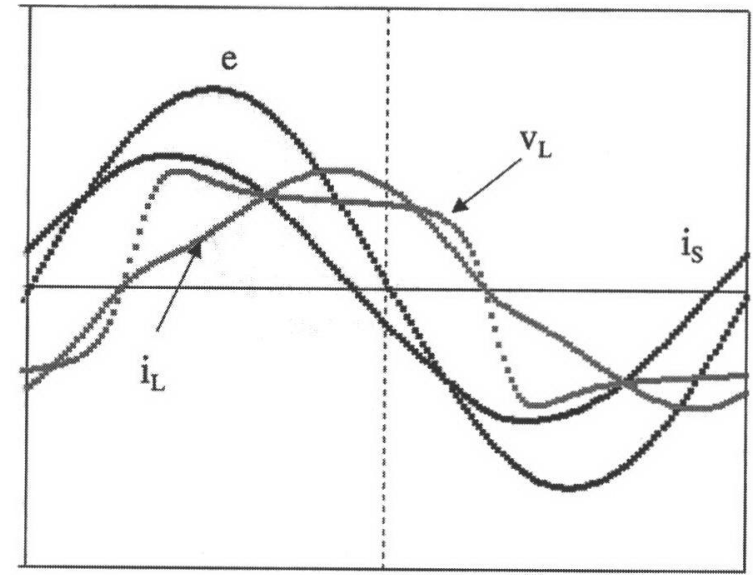

図12 消灯ランプ発生時のシミュレーション

Fig.12 Simulation waveforms in case of the non- lighting lamp occurrence.

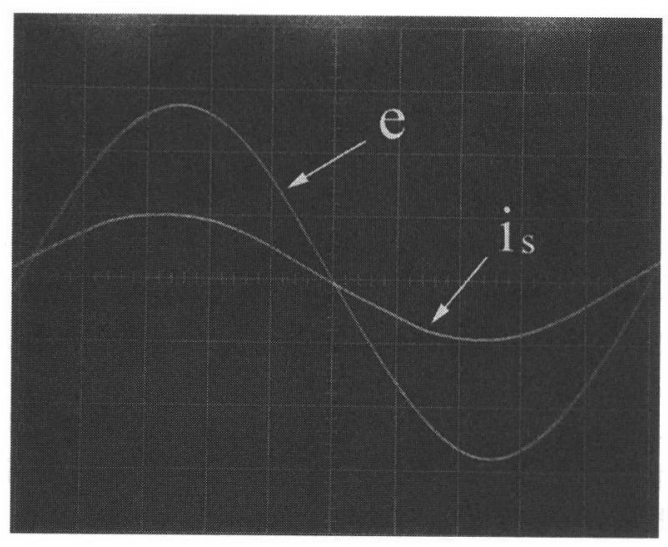

図13 消灯ランプ発生時の実測波形

(e:100V/div, $\left.i_{\mathrm{s}}: 5 \mathrm{~A} / \mathrm{div}\right)$

Fig.13 Experimental waveforms in case of the non- lighting lamp occurrence.

灯ランプが発生した場合のシミュレーション結果と実測結果を示 す。なお，モデル定数 $A_{\mathrm{A}}, C_{\mathrm{C}}$ は，それぞれ $8.77,13.5 \times 10^{4}$ であ る.また, 図12に消灯ランプが発生した時のシミュレーション波 形を, 図13に電源電圧, 電流の実測波形を示す。 
バイパス回路共用複数灯点灯回路において安定状態で消灯ラン プが発生した場合，他のランプは点灯を続けることが実験により 確認された。表 2 より, シミュレーションより求めた電源電流, 電源電力などの值は, 実測值とほぼ一致している.また, 図 12 , 四13より，シミュレーションと実測の波形を比較すると電源電圧 $e$ と電源電流 $i_{\mathrm{S}}$ の位相差は若干異なるが, その形状はほぼ一致し ている。また, 消灯ランプが発生していない時と比べ, 力率が若 干悪くなるが, 電源電流ひずみ率や電源電流の大きさ等には大き な変化はない. したがって, バイパス回路共用複数灯点灯回路は, 使用中に消灯ランプが発生しても実用上は支障がないと言える.

\section{4. 安定器損失の低減対策}

これまでに, バイパス回路共用複数点灯回路において複数ラン プを同時に始動することを可能にするためには, 安定器卷線の電 源側の抵抗を大きくする必要があり, 四11に示すように始動抵抗 $R_{\mathrm{S}}$ を接続しなければならないことを報告した2(3). しかし，この抵 抗による損失が発生するため, 効率が悪くなることが考えられる. そこで, 今回, 新たに抵抗 $R_{\mathrm{S}}$ を点灯直後に直後に短絡するための スイッチ（SW）を設けた.

表 3 に $200 \mathrm{~W}$ バイパス回路共用 4 灯点灯回路（タップ位置 1 / 5 ) を用いて，抵抗 $R_{\mathrm{S}}$ を点灯直後に短絡した場合としなかった場 合の実測結果の比較を示す. その結果, 始動抵抗 $R_{\mathrm{S}}$ が $8 \Omega$ の き, 始動抵抗 $R_{\mathrm{S}}$ を短絡することにより効率 $\left(P_{\mathrm{L}} / P_{\mathrm{i}}\right)$ が $4 \%$ 向上す ることが分かった.すなわち, 始動抵抗 $R_{\mathrm{S}}$ を短絡することにより, $R_{\mathrm{S}}$ による損失がなくなるため, 点灯回路全体の効率が向上すると 言える.

\section{5.まとめ}

著者らは, 高圧水銀ランプバイパス回路共用複数灯点灯回路の 始動特性及び消灯ランプ発生時の諸特性などを明らかにした。す なわち, 始動特性については, 調和平衡法により始動時の等価回 路を求め, 点灯回路の基本波インピーダンスのベクトル軌跡をも とに始動時から安定状態までの始動電流特性を示した。消灯ラン プ発生時の諸特性については, シミュレーションと実測結果より 諸特性を求め, 消灯ランプ発生時も実用上支障がないことを明ら かにした.

本研究の結果を要約すると以下のとおりである.

（1） ランプの基本波インピーダンスは，ランプ電圧の上昇と共に 大きくなるが, バイパス回路の働きにより入力端子の基本波イ ンピーダンスの大きさは始動時から安定状態までほぼ一定であ る.したがって, 始動時から安定状態まで電源電流はほぼ一定 となる。

（2） 大力端子のインピーダンスは，始動時には誘導性であるが， 安定状態に近づくにつれて容量性の方向に変化し, 安定状態で は抵抗成分のみとなり，力率はほぼ100\%となる。

（3）従来の遅相形点灯回路と比較して, 始動電流が小さいこと,

表 3 始動抵抗 $R_{\mathrm{S}}$ の短絡効果

Table 3 The effect by short circuit of starting resistance.

\begin{tabular}{|c|c|c|c|c|c|}
\hline $\begin{array}{c}\text { 始動抵抗 } \\
R_{\mathrm{S}}(\Omega)\end{array}$ & $\begin{array}{c}\text { 電源電流 } \\
I_{\mathrm{S}}(\mathrm{A})\end{array}$ & $\begin{array}{c}\text { 電源電力 } \\
P_{\mathrm{l}}(\mathrm{W})\end{array}$ & $\begin{array}{c}\text { ランプ電流 } \\
I(\mathrm{~A})\end{array}$ & $\begin{array}{c}\text { ランプ電力 } \\
P_{\mathrm{L}}(\mathrm{W}) \\
(\times 4 \text { 灯 })\end{array}$ & $P_{\mathrm{L}} / P_{\mathrm{I}}$ \\
\hline 3.3 & 4.61 & 910 & 1.95 & 880 & 96.7 \\
\hline 8.0 & 4.59 & 900 & 1.85 & 840 & 93.3 \\
\hline 短絡 & 4.68 & 925 & 2.05 & 900 & 97.3 \\
\hline
\end{tabular}

力率が良いことなどから省エネルギーにつながるほか, 回路の 電流容量の縮小などの利点がある.

(4) 安定状態で消灯ランプが発生すると, 力率が数\%悪くなるが, 他のランプには影響がなく実用上問題はない.

(5) 始動時の同時点灯を可能にするために接続した始動抵抗を点 灯直後に短絡することにより, 安定器損失が低減でき, 点灯回 路全体の効率が向上する.

\section{参 考 文 献}

(1) 家村, 中村, 黒住, 山口: 高圧水銀ランプ同相形点灯回路 の考察, 電学論 A, 115-11, pp.1062-1071 (1995).

(2) 家村, 野中, 黒住, 武内, 押方, 須永, 高妻, 山口：高圧 水銀ランプバイパス回路共用複数灯点灯回路に関する考 察, 電学論 A, 120-7, pp.741-749 (2000).

(3) Nonaka, T. and Iemura, M. : The Plural Operating Circuits of Plural Lamps on Common By-pass Circuit for High-pressure Mercury Discharge, Conference Record of the 2000 IEEE industry Applications Conference, Volume 5, pp.3407-3414 (2000).

(4) 家村, 黒住, 山口: バイパス回路付き高圧水銀ランプ遅相 形点灯回路の最適タップ位置, 電学論 A, 114-5, pp.361369 (1994).

(5) 桝見, 坊：水銀ランプ点灯回路のシミュレーションによる 解析, 照学誌, 59-5, p.194 (1975).

(受付日 2001 年 2 月 5 日 $/$ 採録日 2001 年 5 月 31 日)

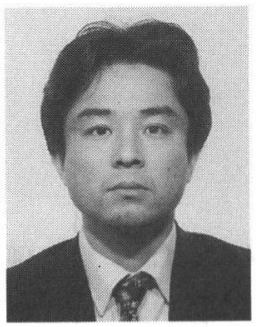

\section{野中 正綱（非会員）}

株式会社九電工研究開発センター

1970年12月 1 日生. 1995年 3 月大分大学大 学院工学研究科修士課程修了. 同年。 4 月 (株) 九電工入社. 主として, 高圧水銀ランプ点灯回路の高調波電流低 減化と力率改善に関する研究に従事. 電気学会会員, 電気設備学 会会員.

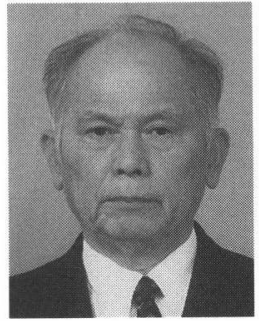

\section{家村 道雄（正会員）}

崇城大学: (旧名：熊本工業大学) 電気工学科

1937年 1 月 4 日生. 1961年 3 月鹿児島大学 工学部電気工学科卒業. 1964年 92年宮崎県 立日向工業高校, 都城工業高校, 宮崎工業高 校(生徒指導主事, 電気科科長)。同年 4 月崇城大学講師, 1994年 4 月同助教授, 1997年 4 月同教授となり, 現在に至る。この間, 放電ランプ点灯回路の高調波電流低減化に関する研究に従事. 工 学博士. 1981年オーム奨学賞, 1992年電気設備学会賞受賞. 電気 学会会員, 電気設備学会会員. 